\title{
Identification and characterization of bacteria with antibacterial activities isolated from seahorses (Hippocampus guttulatus)
}

\author{
José L Balcázar ${ }^{1,2}$, Sara Loureiro ${ }^{1}$, Yolanda J Da Silva ${ }^{1}$, José Pintado ${ }^{1}$ and Miquel Planas ${ }^{1}$ \\ The Journal of Antibiotics (2010) 63, 271-274; doi:10.1038/ja.2010.27; published online 26 March 2010
}

Keywords: antagonism; marine bacteria; seahorses; Vibrio species

Seahorse populations have declined in the last years, largely due to overfishing and habitat destruction. ${ }^{1}$ Recent research efforts have, therefore, been focused to provide a better biological knowledge of these species. We have recently studied, as part of the Hippocampus project, wild populations of seahorse (Hippocampus guttulatus) in some areas of the Spanish coast and established breeding programs in captivity. ${ }^{2}$

With the development of intensive production methods, it has become apparent that diseases can be a significant limiting factor. Vibrio species are among the most important bacterial pathogens of marine fish. They are responsible for several diseases, and high mortalities due to vibriosis have been reported. ${ }^{3,4}$ Thus, we have screened marine bacteria isolated from the intestinal content and cutaneous mucus of seahorses ( $H$. guttulatus) for production of antibacterial compounds against pathogenic Vibrio species. This mechanism of competition offers the possibility of using these antagonistic microorganisms as biological control agents. ${ }^{5-7}$

Adult seahorses $(n=8)$ were collected from the coast of Galicia (NW Spain). The culturable microbiota was isolated from the intestinal content and cutaneous mucus as follows. Intestinal content from each seahorse was collected, weighed homogenized using tissue grinders, and vortexed vigorously in sterile saline solution $\left(8.5 \mathrm{gl}^{-1} \mathrm{NaCl}\right)$, whereas the cutaneous mucus was collected from the dorsal surface with a sterile cotton swab into a small amount of sterile saline solution. Tenfold serial dilutions of samples were prepared and plated on marine agar (Difco, Detroit, MI, USA), tryptic soy agar supplemented with $15 \mathrm{gl}^{-1} \mathrm{NaCl}$ (Cultimed, Barcelona, Spain) and Cytophaga agar prepared with $50 \%$ seawater $\left(0.5 \mathrm{gl}^{-1}\right.$ tryptone, $0.5 \mathrm{gl}^{-1}$ yeast extract, $0.2 \mathrm{gl}^{-1}$ sodium acetate, $15 \mathrm{gl}^{-1}$ agar and adjusted to $\mathrm{pH} 7.2$ ). All plates were incubated for $3-7$ days at $20^{\circ} \mathrm{C}$. Colonies with different morphological characteristics from each sample were selected, subcultured in suitable media and stored in sterile glycerol $(15 \% \mathrm{v} / \mathrm{v})$ at $-80^{\circ} \mathrm{C}$.
To test the ability of the isolates to inhibit growth of pathogenic Vibrio strains (Table 1), we grew all isolates on suitable agar media at $20^{\circ} \mathrm{C}$ for 2-3 days. After incubation, we spotted a loop of each isolate onto the surface of marine agar previously inoculated with overnight cultures of the indicator strain. Clear zones after overnight incubation at $20^{\circ} \mathrm{C}$ indicated the presence of antibacterial substances.

Bacterial isolates showing antagonistic activity against pathogenic Vibrio strains were identified using the 16S rRNA gene, amplified from extracted genomic DNA with primers $27 \mathrm{~F}$ and $907 \mathrm{R}$ and Taq DNA polymerase (Invitrogen, Carlsbad, CA, USA). ${ }^{8} \mathrm{PCR}\left(95^{\circ} \mathrm{C}\right.$ for $10 \mathrm{~min}$; 30 cycles of $94{ }^{\circ} \mathrm{C}$ for $30 \mathrm{~s}, 50^{\circ} \mathrm{C}$ for $1 \mathrm{~min}$ and $72^{\circ} \mathrm{C}$ for $2 \mathrm{~min}$; and $72^{\circ} \mathrm{C}$ for $10 \mathrm{~min}$ ) yielded products of approximately $0.9 \mathrm{~kb}$, which underwent sequencing. The sequences obtained were compared to those available in the GenBank, EMBL and DDBJ databases with the BLAST program (NCBI, Bethesda, MD, USA). ${ }^{9}$ Sequences were subsequently integrated within the ARB program (Munich, Germany) package and analyzed with its alignment tools. ${ }^{10}$ The phylogenetic tree was constructed by the neighbor-joining method with Jukes Cantor correction. The robustness of the tree topology was verified through calculating bootstrap values for the neighbor-joining tree and through comparison with the topology of a maximum likelihood tree, calculated by using the default settings in ARB. ${ }^{10}$

All antagonistic isolates were also studied for the characterization of antibacterial substances. Antagonistic isolates were grown in $100 \mathrm{ml}$ of marine broth without agitation at $20^{\circ} \mathrm{C}$ for 2 days. After incubation, we removed the bacteria by centrifugation $(2000 \mathrm{~g})$, and cell-free culture supernatants were recovered by passage through $0.22 \mu \mathrm{m}$ pore size filters.

All cell-free culture supernatants were adjusted to $\mathrm{pH} 6.5$ with $5 \mathrm{M}$ $\mathrm{NaOH}$ to eliminate the inhibitory effects produced by organic acids. Moreover, sensitivity of cell-free culture supernatants to trypsin and proteinase K (Sigma Chemical Co., St Louis, MO, USA) at a final

\footnotetext{
${ }^{1}$ Instituto de Investigaciones Marinas, Consejo Superior de Investigaciones Científicas, Vigo, Spain and ${ }^{2}$ Catalan Institute for Water Research (ICRA), Scientific and Technological Park of the University of Girona, Girona, Spain

Correspondence: Dr JL Balcázar, Instituto de Investigaciones Marinas, Consejo Superior de Investigaciones Científicas, Eduardo Cabello 6, Vigo 36208, Spain.

E-mail: balcazar@iim.csic.es
}

Received 24 December 2009; revised 18 February 2010; accepted 8 March 2010; published online 26 March 2010 
Table 1 Effect of proteolytic enzymes on the activity of the cell-free culture supernatants

\begin{tabular}{|c|c|c|c|c|c|c|}
\hline \multirow[b]{2}{*}{ Bacterial strain producers } & \multirow[b]{2}{*}{$\begin{array}{l}\text { Enzyme } \\
\text { treatment }\end{array}$} & \multicolumn{5}{|c|}{ Indicator strains ${ }^{\mathrm{a}}$} \\
\hline & & $\begin{array}{l}\text { V. alginolyticus } \\
\text { N26-1 }\end{array}$ & $\begin{array}{c}\text { V. harveyi } \\
\text { HT351 }\end{array}$ & $\begin{array}{c}\text { V. ichthyoenteri } \\
\text { HT21 }\end{array}$ & $\begin{array}{c}\text { V. parahaemolyticus } \\
\text { HT352 }\end{array}$ & $\begin{array}{l}\text { V. splendidus } \\
\text { HT29 }\end{array}$ \\
\hline \multirow[t]{3}{*}{ Brachybacterium sp. strain $\mathrm{HG}-2 \mathrm{~F}$} & Control $^{b}$ & + & + & + & + & + \\
\hline & Proteinase $\mathrm{K}$ & + & + & + & + & + \\
\hline & Trypsin & + & + & + & + & + \\
\hline Vibrio sp. strain $\mathrm{HG}-3 \mathrm{~F}$ & Trypsin & - & - & - & ++ & ++ \\
\hline \multirow[t]{3}{*}{ Pseudoalteromonas ruthenica strain $\mathrm{HG}-4 \mathrm{~F}$} & Control & + & ++ & ++ & ++ & ++ \\
\hline & Proteinase $\mathrm{K}$ & + & ++ & ++ & ++ & ++ \\
\hline & Trypsin & + & ++ & ++ & ++ & ++ \\
\hline \multirow[t]{2}{*}{ Neptunomonas naphthovorans strain HG-6F } & Control & + & + & + & + & ++ \\
\hline & Proteinase $\mathrm{K}$ & + & + & + & + & ++ \\
\hline \multirow[t]{3}{*}{ Aquimarina sp. strain $\mathrm{HG}-9 \mathrm{~F}$} & Control & + & + & + & + & ++ \\
\hline & Proteinase $\mathrm{K}$ & + & + & + & + & ++ \\
\hline & Trypsin & + & + & + & + & ++ \\
\hline \multirow[t]{3}{*}{ Pseudoalteromonas sp. strain HG-10F } & Control & ++ & ++ & ++ & ++ & ++ \\
\hline & Proteinase $\mathrm{K}$ & ++ & ++ & ++ & ++ & ++ \\
\hline & Trypsin & ++ & ++ & ++ & ++ & ++ \\
\hline \multirow[t]{3}{*}{ Jannaschia donghaensis strain $\mathrm{HG}-11 \mathrm{~F}$} & Control & + & + & + & + & + \\
\hline & Proteinase $\mathrm{K}$ & + & + & + & + & + \\
\hline & Trypsin & + & + & + & + & + \\
\hline \multirow[t]{3}{*}{ Aliivibrio fischeri strain $\mathrm{HG}-12 \mathrm{~F}$} & Control & - & - & + & + & ++ \\
\hline & Proteinase $\mathrm{K}$ & - & - & - & - & - \\
\hline & Trypsin & - & - & - & - & - \\
\hline \multirow{2}{*}{ Pseudomonas sp. strain HG-15F } & Proteinase $\mathrm{K}$ & + & + & + & + & + \\
\hline & Trypsin & + & + & + & + & + \\
\hline \multirow[t]{3}{*}{ Shewanella sp. strain HG-17F } & Control & + & + & + & + & + \\
\hline & Proteinase $\mathrm{K}$ & + & + & + & + & + \\
\hline & Trypsin & + & + & + & + & + \\
\hline
\end{tabular}

Diameter of inhibition zone:,$+ 6-10 \mathrm{~mm} ;++,>10 \mathrm{~mm} ;-$, no inhibition zone.

aVibrio species isolated from disease processes in seahorses.

bControl samples consisting of cell-free supernatants without enzyme treatment.

concentration of $1.0 \mathrm{mg} \mathrm{ml}^{-1}$ was also tested in buffers recommended by the supplier. Samples with and without enzymes were incubated at $37^{\circ} \mathrm{C}$ for $2 \mathrm{~h}$ and residual activity was determined. To exclude potential inhibition by hydrogen peroxide, we added catalase (Sigma Chemical Co.) at a final concentration of $0.5 \mathrm{mg} \mathrm{ml}^{-1}$ and incubated at $37^{\circ} \mathrm{C}$ for $30 \mathrm{~min}$. All assays were independently repeated at least two times for reproducibility.

Indicator bacteria ( $V$. alginolyticus N26-1, V. harveyi HT351, V. ichthyoenteri HT21, V. parahaemolyticus HT352 and V. splendidus HT29) were grown in $5 \mathrm{ml}$ of tryptic soy broth supplemented with $1.5 \% \mathrm{NaCl}$ at $20^{\circ} \mathrm{C}$ for $24 \mathrm{~h}$. The cells were harvested by centrifugation $(2000 \mathrm{~g})$, washed twice with sterile saline solution and resuspended in $5 \mathrm{ml}$ of the same solution. The bacterial suspensions were transferred to marine agar plates. Four wells were made in each agar plate with a sterile Pasteur pipette, and cell-free culture supernatants $(10 \mu \mathrm{l})$ from the isolates were placed into each well. The plates were incubated aerobically at $20^{\circ} \mathrm{C}$ for $1-2$ days and then examined for zones of inhibition.

In all, 250 bacterial isolates from the intestinal content and cutaneous mucus were analyzed. Only 13 of these produced zones of inhibition, ranging from 15 to $20 \mathrm{~mm}$, against at least one of the indicator strains. Comparative 16S rRNA gene sequence analysis placed the antagonistic isolates in the Gammaproteobacteria (61.5\%), Alphaproteobacteria (23.1\%), in the CFB group of Bacteroidetes (7.7\%) and Actinobacteria (7.7\%). Bacterial isolates belonging to the Gammaproteobacteria were obtained exclusively from the intestinal content. In particular, the genera Aliivibrio, Neptunomonas, Pseudoalteromonas, Pseudomonas, Shewanella and Vibrio were identified (Figure 1). The Alphaproteobacteria were 


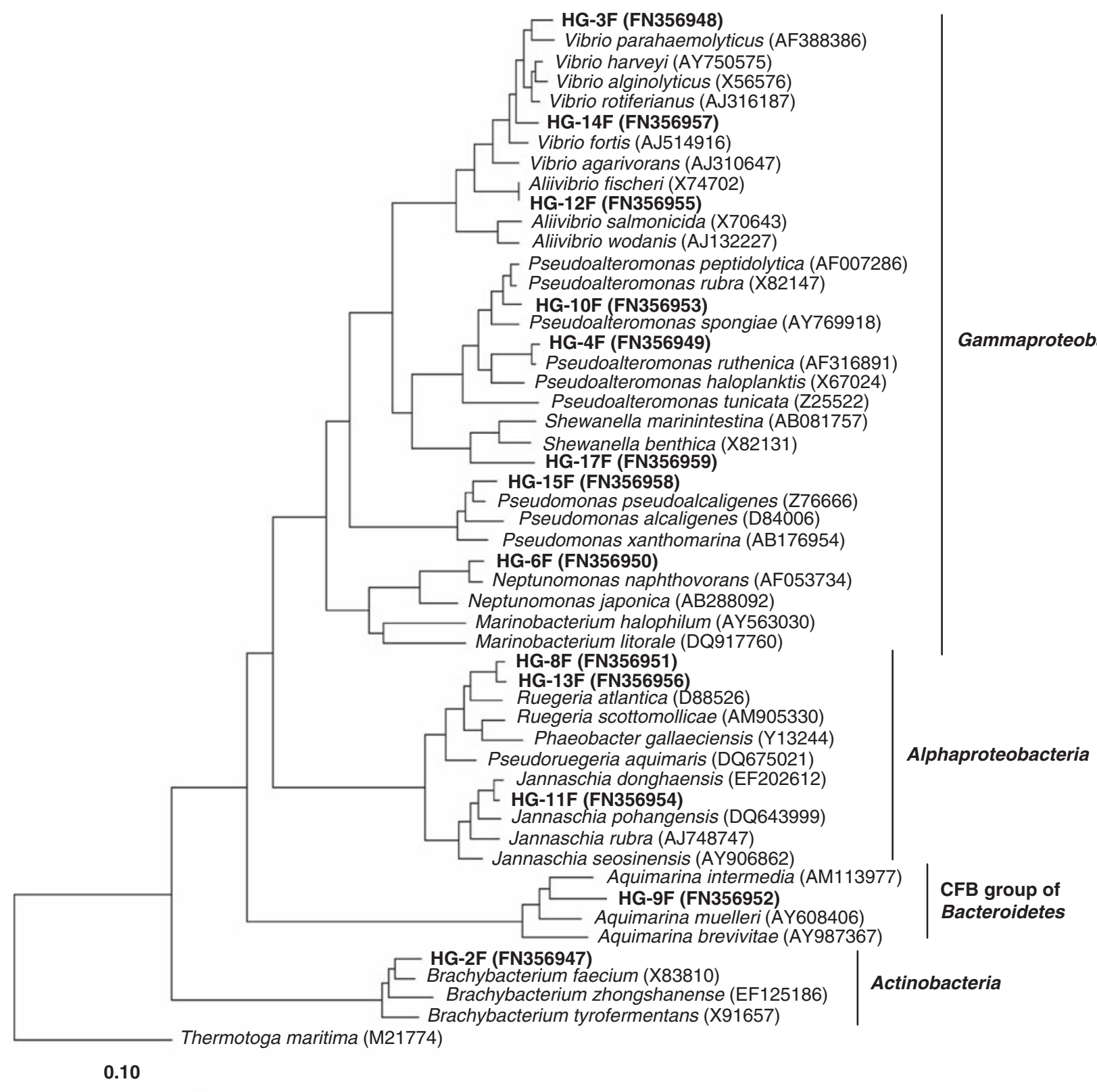

Figure 1 Phylogenetic tree of antagonistic isolates with the most closely related bacterial species, based on 16S rRNA gene sequences and constructed by the neighbor-joining method. Sequences determined in this study are shown in boldface type. Thermotoga maritima DSM 3109T was used as an out-group. The scale bar corresponds to 0.1 substitutions per nucleotide.

represented by the genera Ruegeria and Jannaschia, which were isolated from the cutaneous mucus. Members of the CFB group of Bacteroidetes and Actinobacteria were also identified from the cutaneous mucus samples (Figure 1).

The cell-free culture supernatants from the 13 antagonistic isolates exhibited antibacterial activity against at least one of the indicator strains (Table 1). Except for Vibrio sp. HG-3F, Alivibrio fischeri HG-12F and Vibrio sp. HG-14F, the antibacterial activities were completely lost when the cell-free culture supernatants were neutralized to pH 6.5 (data is not shown), suggesting that the antibacterial activity of these isolates could be attributed to the production of organic acids or $\mathrm{pH}$-dependent compounds.

Inhibitory activity of the cell-free culture supernatants generally was not inactivated by enzyme treatment, which indicates that the inhi- bitory compounds are not proteinaceous (Table 1). The only exceptions were the cell-free culture supernatants from Vibrio sp. HG-3F, A. fischeri HG-12F and Vibrio sp. HG-14F, which were inactivated by at least one proteolytic enzyme. These findings suggest that the inhibitory substances produced by these three isolates are proteinaceous, which show similar biological activities to bacteriocin or bacteriocin-like inhibitory substances.

Bacteriocins are ribosomally synthesized peptides or proteins that are generally effective against closely related species. ${ }^{11}$ Evidence is abundant that bacteriocins are important mediators of intra- and interspecies interactions and, consequently, a significant factor in maintaining microbial biodiversity. ${ }^{12}$ Although research efforts have mainly focused on bacteriocins produced by Gram-positive bacteria, bacteriocin production has also been reported in Gram-negative bacteria. Recent studies 
have shown bacteriocin or bacteriocin-like inhibitory substance production by $V$. harveyi, V. mediterranei and $V$. vulnificus. ${ }^{13-15}$ In this study, the isolate HG-3F, closely related to V. parahaemolyticus ( $97.6 \%$ similarity), showed inhibitory activity only against indicator strains of $V$. parahaemolyticus and V. splendidus. Moreover, the isolate HG-12F, identified as $A$. fischeri ( $100 \%$ similarity), showed inhibitory activity only against indicator strains of $V$. ichthyoenteri, $V$. parahaemolyticus and $V$. splendidus. Finally, the isolate HG-14F, closely related to V. rotiferianus ( $98.5 \%$ similarity), inhibited all indicator strains. The fact that bacteriocin or bacteriocin-like inhibitory substances can have similar or different immunity proteins could explain these results. ${ }^{16}$

In conclusion, in addition to showing that bacteria associated with seahorses are able to produce antibacterial compounds, we have shown that some of these compounds are proteinaceous. The genus Vibrio includes several species pathogenic to fish and humans, some of which are resistant to chemotherapeutic treatment. ${ }^{17}$ Therefore, the potential as biological control agents of isolates exhibiting inhibitory activities against such species could be further studied in challenge experiments in fish or other marine species.

\section{ACKNOWLEDGEMENTS}

This study was financed by the Spanish Ministry of Science and Technology (Hippocampus CGL2005-05927-C03-01). JLB was supported by a postdoctoral I3P contract from the Spanish Council for Scientific Research (CSIC). YJS was granted by the Erasmus program (29154-IC-1-2007-1-PT-ERASMUS-EUC-1). We thank Dr AF Moldenke for her critical comments on the paper.

1 Curtis, J. M. R. \& Vincent, A. C. J. Use of population viability analysis to evaluate CITES trade-management options for threatened marine fishes. Conserv. Biol. 22, 12251232 (2008).
2 Planas, M., Chamorro, A., Quintas, P. \& Vilar, A. Establishment and maintenance of threatened long-snouted seahorse, Hippocampus guttulatus, broodstock in captivity. Aquaculture 283, 19-28 (2008).

3 Actis, L. A., Tolmasky, M. E. \& Crosa, J. H. Fish diseases and disorders: viral, bacterial and fungal infections. in Vibriosis (eds Stevenson, R.M. \& Woo, P.T.) 523-557 (CAB International, Wallingford, 1999).

4 Balcázar, J. L., Gallo-Bueno, A., Planas, M. \& Pintado, J. Isolation of Vibrio alginolyticus and Vibrio splendidus from captive-bred seahorses with disease symptoms. Antonie van Leeuwenhoek. 97, 207-210 (2010).

5 Balcázar, J. L. et al. The role of probiotics in aquaculture. Vet. Microbiol. 114 173-186 (2006)

6 Balcázar, J. L. et al. In vitro competitive adhesion and production of antagonistic compounds by lactic acid bacteria against fish pathogens. Vet. Microbiol. 122, 373-380 (2007)

7 Teplitski, M., Wright, A. C. \& Lorca, G. Biological approaches for controlling shellfishassociated pathogens. Curr. Opin. Biotechnol. 20, 185-190 (2009).

8 So, C. M. \& Young, L. Y. Isolation and characterization of a sulfate-reducing bacterium that anaerobically degrades alkanes. Appl. Environ. Microbiol. 65, 2969-2976 (1999).

9 Altschul, S. F., Gish, W., Miller, W., Myers, E. W. \& Lipman, D. J. Basic local alignment search tool. J. Mol. Biol. 215, 403-410 (1990).

10 Ludwig, W. et al. ARB: a software environment for sequence data. Nucleic Acids Res. 32, 1363-1371 (2004).

11 Jack, R. W., Tagg, J. R. \& Ray, B. Bacteriocin of Gram-positive bacteria. Microbiol Rev. 59, 171-200 (1995).

12 Riley, M. A. Molecular mechanisms of bacteriocin evolution. Annu. Rev. Genet. 32, 255-278 (1998).

13 Shehane, S. D. \& Sizemore, R. K. Isolation and preliminary characterization of bacteriocins produced by Vibrio vulnificus. J. Appl. Microbiol. 92, 322-328 (2002).

14 Prasad, S., Morris, P. C., Hansen, R., Meaden, P. G. \& Austin, B. A novel bacteriocinlike substance (BLIS) from a pathogenic strain of Vibrio harveyi. Microbiology 151, 3051-3058 (2005).

15 Carraturo, A., Raieta, K., Ottaviani, D. \& Russo, G. L. Inhibition of Vibrio parahaemolyticus by a bacteriocin-like inhibitory substance (BLIS) produced by Vibrio mediterranei 1. J. Appl. Microbiol. 101, 234-241 (2006).

16 Mélançon, D. \& Grenier, D. Production and properties of bacteriocin-like inhibitory substances from the swine pathogen Streptococcus suis serotype 2. Appl. Environ. Microbiol. 69, 4482-4488 (2003).

17 Ottaviani, D. et al. Antimicrobial susceptibility of potentially pathogenic halophilic vibrios isolated from seafood. Int. J. Antimicrob. Agents 18, 135-140 (2001). 